This Accepted Author Manuscript is copyrighted and published by Elsevier. It is posted here by agreement between Elsevier and University of Brasilia. Changes resulting from the publishing process - such as editing, corrections, structural formatting, and other quality control mechanisms - may not be reflected in this version of the text. The definitive version of the text was subsequently published in [Animal Reproduction Science, Volume 107, Issue 3-4, June 2012, Pages 159-168, doi:10.1016/j.anireprosci.2012.05.017].You may download, copy and otherwise use the AAM for non-commercial purposes provided that your license is limited by the following restrictions:

(1) You may use this AAM for non-commercial purposes only under the terms of the CC-BY-NCND license.

(2) The integrity of the work and identification of the author, copyright owner, and publisher must be preserved in any copy.

(3) You must attribute this AAM in the following format: [agreed attribution language, including link to CC BY-NC-ND license + Digital Object Identifier link to the published journal article on Elsevier's ScienceDirect ${ }^{\circledR}$ platform].

Este Manuscrito do Autor Aceito para Publicação (AAM) é protegido por direitos autorais e publicado pela Elsevier. Ele esta disponível neste Repositório, por acordo entre a Elsevier e a Universidade de Brasília. As alterações decorrentes do processo de publicação - como a edição, correção, formatação estrutural, e outros mecanismos de controle de qualidade - não estão refletidas nesta versão do texto. A versão definitiva do texto foi posteriormente publicado em [Animal Reproduction Science, Volume 107, Número 3-4, Junho 2012, Pages 159-168, doi:10.1016/j.anireprosci.2012.05.017]. Você pode baixar, copiar e utilizar de outra forma o AAM para fins não comerciais , desde que sua licença seja limitada pelas seguintes restrições:

(1) Você pode usar este AAM para fins não comerciais apenas sob os termos da licença CC- BYNC-ND.

(2) A integridade do trabalho e identificação do autor, detentor dos direitos autorais e editor deve ser preservado em qualquer cópia.

(3) Tem de atribuir este AAM no seguinte formato: [acordo na linguagem atribuída, incluindo o link para CC BY-NC-ND licença Digital + DOI do artigo publicado na revista Elsevier ScienceDirect ${ }^{\circledR}$ da plataforma]. 


\title{
Effect of sequential medium on in vitro culture of goat ovarian cortical tissue
}

D.M. Magalhães-Padilha

P.M. Andrade

E.T. Sales

V.R. Araujo

I.M.T. Lima

S.V. Castro

L.R. Faustino

C.A.P. Lopes

C.C. Campello

S.N. Báo

M.O. Gastal

E.L. Gastal

J.R. Figueiredo

\begin{abstract}
A sequential medium was evaluated on the survival, activation and growth rates of caprine preantral follicles submitted to a long-term culture period, aiming to establish an ideal in vitro culture system. Ovarian fragments were cultured for 16 days in $\alpha-M E M+$ alone or supplemented with hormones ( $\mathrm{GH}$ and/or FSH) added sequentially on different days of culture. Ovarian fragments were cultured in the first (days 0-8) and second (days 8-16) halves of the culture period, generating 10 treatments: $\alpha-M E M+/ \alpha-M E M+, F S H / F S H, F S H / G H, F S H / F S H+G H$, $\mathrm{GH} / \mathrm{GH}, \mathrm{GH} / \mathrm{FSH}, \mathrm{GH} / \mathrm{FSH}+\mathrm{GH}, \mathrm{FSH}+\mathrm{GH} / \mathrm{FSH}+\mathrm{GH}, \mathrm{FSH}+\mathrm{GH} / \mathrm{FSH}$ and $\mathrm{FSH}+\mathrm{GH} / \mathrm{GH}$. Follicle morphology, viability and ultrastructure were analyzed. After day 1 of culture, FSH treatments maintained the percentage of normal follicles similar to the fresh control. At day 16 of culture, the treatment $\mathrm{FSH} / \mathrm{GH}$ showed the highest $(\mathrm{P}<0.05)$ percentage of normal follicles. The ultrastructure of follicles was preserved in the fresh control and FSH/GH treatment. Follicles cultured with $\mathrm{FSH} / \mathrm{GH}$ had a higher $(\mathrm{P}<0.05)$ viability than $\alpha-\mathrm{MEM}+$; however the viability was lower $(\mathrm{P}<0.05)$ when compared to the fresh control. The FSH/GH treatment showed the highest $(P<0.05)$ percentage of follicular activation and secondary follicle formation and produced the largest $(P<0.05)$ mean follicular diameter after 16 days of culture. In conclusion, a sequential medium supplemented with FSH followed by GH during a long-term culture maintains the survival, viability and ultrastructure of goat preantral follicles, and promotes activation and secondary follicles.
\end{abstract}

Keywords: Caprine; Folliculogenesis; FSH; GH; Preantral follicle

\section{Introduction}

The ovarian cortical tissue contains thousands of oocytes enclosed in preantral follicles at birth. The majority of those are primordial follicles, considered to be the resting follicle pool. However, most of these oocytes (99.9\%) undergo atresia during the stages of activation, growth and maturation (Skinner, 2005). Due to this phenomenon, the ovary's ability to produce mature oocytes is quite poor. During recent decades, many researchers in the field of animal reproduction have contributed to an improvement in the biotechnological multiplication of animals of high economic value and endangered species. Among these 
biotechnologies is the in vitro culture of preantral follicles, which despite being a biotechnical complexity, has resulted in the birth of live mice ( O'Brien et al., 2003 and Wang et al., 2011) and the production of viable embryos in some species (rat: Daniel et al., 1989; pig: Wu et al., 2001; buffalos: Gupta et al., 2008; sheep: Arunakumari et al., 2010; goat: Magalhães et al., 2011). Despite these promising results, the exact mechanisms responsible for the activation and subsequent growth and development of primordial follicles remain unclear.

Follicular development is controlled by a complex interaction among the pituitary gonadotropins, luteinizing hormone (LH) and follicle-stimulating hormone (FSH) and local factors, such as steroid hormones and growth factors (Gougeon, 1996). The fate of a follicle, therefore, depends on the balance between stimulatory and inhibitory factors in the ovary. Several short-term in vitro culture studies in goats have achieved follicular activation in the presence of growth factors and/or gonadotropins ( Martins et al., 2008, Magalhães et al., 2009 and Celestino et al., 2010). However, only one study in this species has achieved in vitro development from primordial to secondary follicles enclosed in ovarian tissue ( Martins et al., 2008). This suggests that an extended culture period and a sequential medium may be required for preantral follicle development according to different growth phases. Recently, the addition of different growth factors/hormones at different times of culture (i.e., sequential culture medium) stimulated the activation of primordial follicles to later developmental stages in ovine ovarian cortical tissue ( Peng et al., 2010).

Among the hormones involved in folliculogenesis are growth hormone $(\mathrm{GH})$ and follicle stimulating hormone (FSH). GH has been shown to play a role in folliculogenesis through the detection of GH-R immunoreactivity and mRNA encoding GH-R in ovarian tissue in humans (Carlsson et al., 1992) and cows (Kölle et al., 1998). Some in vitro studies suggest that GH plays a role in follicular growth during the early gonadotropin-independent stages of folliculogenesis and could have a direct inhibitory action on follicle apoptosis ( Chun and Hsueh, 1998 and Sirotkin and Makarevich, 1999). Other in vitro studies have demonstrated that the addition of FSH to the culture medium promotes the maintenance of viability and growth of preantral follicles in goats ( Matos et al., 2007 and Magalhães et al., 2009).

In spite of the importance of GH and FSH revealed by the aforementioned in vitro studies, there are no reports regarding the interaction of these hormones added on different days of long-term culture (sequential medium) in cultures of caprine preantral follicles. Therefore, the aim of this study was to investigate the effect of a sequential culture medium supplemented with $\mathrm{GH}$ and/or FSH on the survival, activation and in vitro growth of caprine preantral follicles during long-term (16 days) culture. 


\section{Materials and methods}

\subsection{Chemicals}

All the chemicals and culture media used for this study were purchased from Sigma Chemical Company (St. Louis, MO, USA), unless otherwise stated.

\subsection{Source of ovaries}

Ovarian cortical tissue ( $n=18$ ovaries) was harvested at a local slaughterhouse from nine adult (1-3 years old), cross-breed goats (Capra hircus). Four goats were used for histological analysis and transmission electron microscopy (TEM) and five for fluorescence analysis. Immediately postmortem, the ovaries were washed in $70 \%$ alcohol followed by two washes in Minimum Essential Medium (MEM) supplemented with $100 \mu \mathrm{g} / \mathrm{ml}$ penicillin and 100 $\mu \mathrm{g} / \mathrm{ml}$ streptomycin. The pairs of ovaries were transported to the laboratory in MEM within $1 \mathrm{~h}$ at $4{ }^{\circ} \mathrm{C}$ ( Chaves et al., 2008).

\subsection{Experimental protocol}

The organ culture system utilized herein has been previously described in detail (Magalhães et al., 2009 and Celestino et al., 2010). Briefly, in the laboratory, the ovaries were stripped off the surrounding fat tissues and ligaments. Subsequently, for histological and TEM analyses, ovarian cortex tissue from each ovarian pair from the same animal was cut into 19 slices (approximate size: $3 \mathrm{~mm} \times 3 \mathrm{~mm}$, with $1 \mathrm{~mm}$ thickness) using a scalpel under sterile conditions. One slice was immediately fixed for histological and ultrastructural analysis (fresh control) and the other 18 were placed in culture for 1,8 or 16 days in individual wells. The cortex tissue samples were transferred to 24 -well culture dishes containing $1 \mathrm{ml}$ of culture medium. Culture was performed at $39{ }^{\circ} \mathrm{C}$ in $5 \% \mathrm{CO} 2$ in a humidified incubator and all the media were incubated for $1 \mathrm{~h}$ prior to use. The basic culture medium consisted of $\alpha-M E M(p H$ 7.2-7.4) supplemented with ITS (10 $\mu \mathrm{g} / \mathrm{ml}$ insulin, $5.5 \mu \mathrm{g} / \mathrm{ml}$ transferrin and $5 \mathrm{ng} / \mathrm{ml}$ selenium), $2 \mathrm{mM}$ glutamine, $2 \mathrm{mM}$ hypoxanthine, $1.25 \mathrm{mg} / \mathrm{ml}$ bovine serum albumin (BSA) and $50 \mu \mathrm{g} / \mathrm{ml}$ ascorbic acid, which was called $\alpha-M E M+$ (cultured control). For experimental conditions, the medium was supplemented with human recombinant GH (rGH $10 \mathrm{ng} / \mathrm{ml}$; MP Biomedicals LLC, Eschwege, Germany), bovine recombinant FSH (rFSH 50 ng/ml; Nanocore, São Paulo, Brazil) or GH and FSH in different combinations (Fig. 1). Each treatment was repeated four times and 
applied to one slice from each of 4 goats and the culture media were replenished every other day. The concentrations of GH and FSH used in this work were chosen based on previous studies in our laboratory (Martins et al., 2008 and Magalhães et al., 2009).

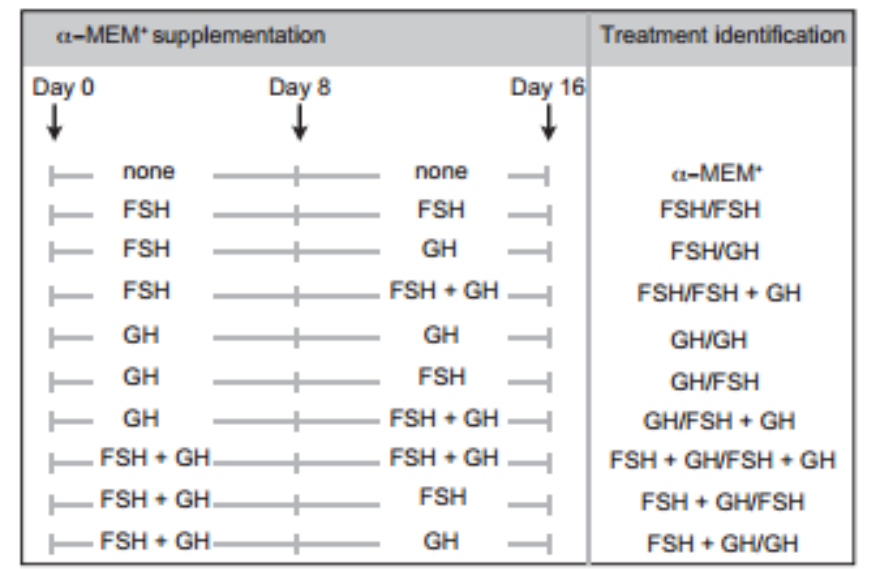

Fig. 1. Tested treatments according to supplementation of the medium for the in vitro culture of caprine ovarian tissues.

\subsection{Morphological analysis and assessment of in vitro follicular growth}

Before culture (fresh control) and after 1, 8 or 16 days in culture, all tissue pieces were fixed in Carnoy's solution for $12 \mathrm{~h}$ and then dehydrated in increasing concentrations of ethanol. After paraffin embedding (Synth, São Paulo, Brazil), the caprine ovarian cortex tissue samples were cut into 7- $\mu \mathrm{m}$ sections, which were mounted on glass slides and stained with periodic acid - Schiff (PAS) - hematoxylin. Follicle stage and morphology were assessed in serial sections using a microscope (Nikon, Tokyo, Japan) under 400x magnification. The developmental stages of follicles have been defined previously (Hulshof et al., 1994) as primordial (one layer of flattened and cuboidal granulosa cells) or growing follicles (primary one layer of cuboidal granulosa cells, and secondary - two or more layers of cuboidal granulosa cells around the oocyte). Follicles were classified as histologically normal when an intact oocyte was present, surrounded by granulosa cells that were well organized in one or more layers and lacked a pyknotic nucleus. Degenerated follicles were defined as those with a retracted oocyte, pyknotic nucleus, and/or disorganized granulosa cells detached from the basement membrane. The percentage of morphologically normal follicles, before (day 0 ) and after culture, indicated the percentage of follicle survival.

Overall, 120 follicles were evaluated for each treatment (30 follicles per treatment in one repetition $\times$ four repetitions $=120$ follicles).

To evaluate follicular activation, the percentages of normal primordial and growing follicles were calculated before (fresh control) and after culture in each treatment. In addition, 
follicle and oocyte diameters were measured in healthy follicles only. Follicle diameter was recorded from edge to edge of the outer layer of granulosa cells or from the outside edge of the theca cell layer when present. Oocyte diameter was recorded from edge to edge of the oocyte membrane. Two perpendicular diameters were recorded in each measurement and the average of these two values was calculated. Each follicle was examined in the section in which its oocyte appeared in the largest cross section and matched with the same follicle on adjacent sections to avoid double counting, thus ensuring that each follicle was only counted once.

\subsection{Ultrastructural analysis}

To better evaluate follicular morphology, ultrastructural analysis was performed on preantral follicles from non-cultured tissue (control), follicles cultured in $\alpha-M E M+$ alone, as well as the treatments which demonstrated the best results for morphology, activation, and growth. Small pieces $(1 \mathrm{~mm} 3)$ of tissue were cut off from caprine ovarian fragments before and after each period of culture for each treatment and fixed for $2 \mathrm{~h}$ in a solution containing $2.5 \%$ glutaraldehyde and $4 \%$ formaldehyde in $0.1 \mathrm{M}$ sodium cacodylate buffer, $\mathrm{pH}$ 7.2. After fixation, the fragments were washed three times with $0.1 \mathrm{M}$ sodium cacodylate buffer and postfixed in $1 \%$ osmium tetroxide, $0.8 \%$ potassium ferricyanide and $5 \mathrm{mM} \mathrm{CaCl} 2$ in a $0.1 \mathrm{M}$ sodium cacodylate buffer. Next, samples were contrasted with uranyl acetate, dehydrated in a graded series of acetone and embedded in Spurr's epoxy resin. Follicles classified as histologically viable in toluidine blue-stained semi-thin sections $(3 \mu \mathrm{m})$ were submitted to ultrastructural analysis. For that analysis, ultra-thin sections $(60 \mathrm{~nm})$ were cut on an ultramicrotome (Reichert Supernova, Germany) and examined using a Jeol 1011 (Jeol, Tokyo, Japan) transmission electron microscope, operating at $80 \mathrm{kV}$. For ultrastructural analysis, a total of, at least, 5 follicles were examined per group.

\subsection{Assessment of preantral follicle viability by fluorescence microscopy}

To confirm the results of the morphological and ultrastructural analyses, the viability of follicles from fresh control, follicles cultured in $\alpha-M E M+$ alone and follicles cultured in the treatment that provided the best outcome were further analyzed using a more accurate method of assessment based on fluorescent probes. Pairs of goat ovaries $(n=5)$ were cut into fragments; one of which was immediately processed for follicle isolation and the other fragments were cultured in $\alpha-M E M+$ alone and in the treatment that provided the best 
outcome. After the in vitro culture, the cortical slices from both treatments were subjected to follicle isolation.

Goat preantral follicles were isolated from ovarian fragments using a mechanical method described by Lucci et al. (1999). Briefly, a tissue chopper (The Mickle Laboratory Engineering Co., Gomshal, Surrey, UK) was adjusted for a sectioning interval of $75 \mu \mathrm{m}$ and samples were cut into small pieces. The fragments were then placed in $\alpha-M E M+$, resuspended 40 times using a large Pasteur pipette (diameter $\sim 1600 \mu \mathrm{m}$ ) and resuspended again 40 more times with a smaller Pasteur pipette (diameter $\sim 600 \mu \mathrm{m}$ ) in order to dissociate preantral follicles from the ovarian stroma. The material obtained was passed through a $100-\mu \mathrm{m}$ nylon mesh filter, resulting in a suspension containing preantral follicles less than $100 \mu \mathrm{m}$ in diameter. This procedure was carried out at room temperature within a 10-min time frame.

Preantral follicles were analyzed using a two-color fluorescence cell viability assay based on the simultaneous detection of live and dead cells with calcein-AM and ethidium homodimer-1, respectively. While the first probe detects intracellular esterase activity in viable cells, the latter labels nucleic acids in non-viable cells with disrupted plasma membranes. The test was performed by adding $4 \mu \mathrm{M}$ calcein-AM and $2 \mu \mathrm{M}$ ethidium homodimer-1 (Molecular Probes, Invitrogen, Karlsruhe, Germany) to a suspension of isolated follicles, which were then incubated at $37{ }^{\circ} \mathrm{C}$ for $15 \mathrm{~min}$. After being labeled, the follicles were washed once by centrifugation at $100 \times \mathrm{g}$ for $5 \mathrm{~min}$ and resuspended in $\alpha-M E M+$. The cells were then mounted on glass microscope slides in $5 \mu \mathrm{l}$ of anti-fading medium (DABCO, Sigma, Deisenhofen, Germany) to prevent photobleaching, and examined using a fluorescence microscope (Nikon, Eclipse 80i, Tokyo, Japan). The emitted fluorescence signals of calcein-AM and ethidium homodimer-1 were collected at 488 and $568 \mathrm{~nm}$, respectively. Oocytes and granulosa cells were considered viable if their cytoplasm stained positively with calcein-AM (green) and their chromatin was not labeled with ethidium homodimer-1 (red).

\subsection{Statistical analyses}

Initially, all data were submitted to Shapiro-Wilk and Bartlett tests to confirm normal distribution and homoscedasticity, respectively. The percentages of morphologically normal preantral follicles and different follicular classes (primordial and growing follicles) were then submitted to analysis of variance (ANOVA) using the GLM procedure of SAS (Version 1999; Cary, NC), followed by the Student-Newman-Keuls and Duncan tests for a comparison of the means. Follicle and oocyte diameters did not show homogeneity of variance, even after transformation, and were analyzed by Kruskal-Wallis non-parametric test. Data for follicular 
viability assessed through fluorescence microscopy were analyzed as dispersion of frequencies using the $\chi 2$ test. Differences among groups were considered to be significant when $\mathrm{P}<0.05$ and results were expressed as the mean \pm standard deviation (SD).

\section{Results}

\subsection{Caprine preantral follicle survival before and after in vitro culture}

A total of 2280 preantral follicles was analyzed by classical histology. Normal follicles from the fresh control (primordial follicles) and after culture in $\alpha-M E M+$ supplemented with FSH and GH (FSH/GH) (secondary follicle) are shown (Fig. 2A and B). Degenerated follicles after 16 days of culture in $\alpha-M E M+$ alone are also shown (Fig. $2 \mathrm{C}$ ). In the degenerated follicles, retracted oocytes, pyknotic nuclei and disorganized granulosa cells are noticeable.
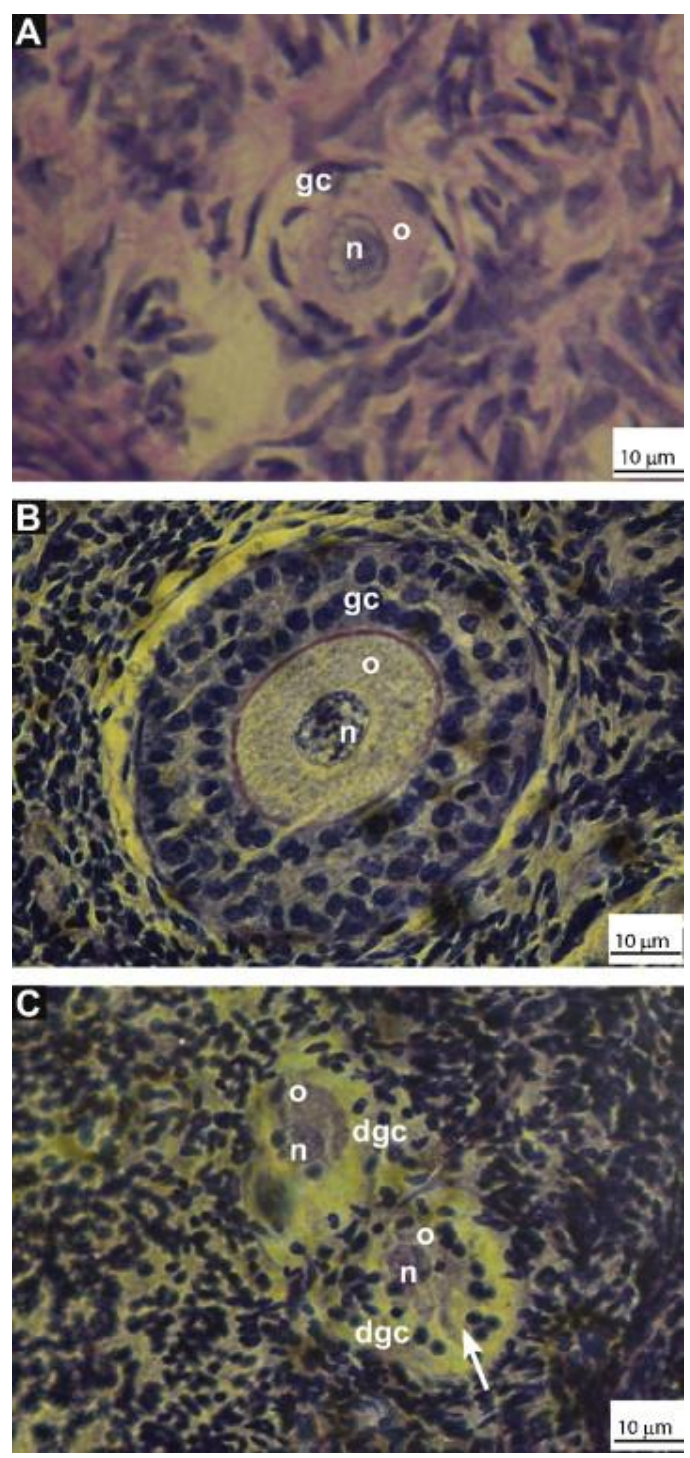
Fig. 2. Histological sections of (A) normal preantral follicle from the fresh control or (B) normal secondary follicle cultured for 16 days in $\mathrm{FSH} / \mathrm{GH}$ treatment and (C) degenerated preantral follicles after 16 days of culture in $\alpha-M E M+$ alone. $o=$ oocyte; $n=$ oocyte nucleus; gc = granulosa cell. Note the retracted oocytes (arrow), and disorganized granulosa cells (dgc).

The percentage of morphologically normal preantral follicles in the fresh control and after 1,8 or 16 days of in vitro culture is shown in Table 1 . After 1 day of culture, there was a reduction $(P<0.05)$ in the percentage of normal follicles in all treatments, compared to the fresh control (91.7\%), except when the culture was performed only with FSH (85.8\%; P > 0.05). In contrast, after 8 and 16 days of culture, the percentage of normal follicles decreased $(P<$ 0.05) in all treatments in comparison to the fresh control. When the treatments were compared, there was a higher percentage of normal follicles in all treatments performed only with FSH in the first half of culture period, i.e. day 8 (81.7\%). Moreover, after 16 days of culture, the treatment FSH/GH showed the highest $(P<0.05)$ percentage of normal follicles (77.5\%). With the progression of the culture period from 1 to 8 days, a decrease $(P<0.05)$ in the percentage of normal follicles was observed only in the treatment $\alpha-M E M+$. However, all treatments showed a further decrease $(P<0.05)$ in the percentage of normal follicles from 8 to 16 days of culture, except the treatment FSH/GH.

Table 1.

Percentages (mean \pm SD) of morphologically normal preantral follicles in non-cultured tissues (fresh control) and in tissues cultured for 1,8 or 16 days in $\alpha-M E M+$ alone or $\alpha-M E M+$ containing GH and/or FSH.

\begin{tabular}{|c|c|c|c|c|}
\hline \multirow[t]{2}{*}{ Treatments } & \multicolumn{4}{|c|}{ Normal preantral follicles (\%) } \\
\hline & Day 0 & Day 1 & Day 8 & Day 16 \\
\hline Control & $91.7 \pm 1.9$ & - & - & - \\
\hline$\alpha-\mathrm{MEM}^{+}$ & & $70.0 \pm 2.7^{\circ \mathrm{bA}}$ & $59.2 \pm 3.2^{\pi \mathrm{dB}}$ & $42.5 \pm 3.2^{* d C}$ \\
\hline $\begin{array}{l}\mathrm{FSH} / \mathrm{FSH}^{\S} \\
\mathrm{FSH} / \mathrm{GH} \\
\mathrm{FSH} / \mathrm{FSH}+\mathrm{GH}\end{array}$ & & $85.8 \pm 3.2^{\mathrm{aA}}$ & $81.7 \pm 1.9^{\mathrm{aAB}}$ & $\begin{array}{l}59.2 \pm 1.7^{\circ \mathrm{bC}} \\
77.5 \pm 3.2^{\circ \mathrm{dB}} \\
62.5 \pm 4.2^{\circ \mathrm{bC}}\end{array}$ \\
\hline $\begin{array}{l}\mathrm{GH} / \mathrm{GH}^{\S} \\
\mathrm{GH} / \mathrm{FSH} \\
\mathrm{GH} / \mathrm{FSH}+\mathrm{GH}\end{array}$ & & $68.3 \pm 1.9^{-b A}$ & $64.2 \pm 3.2^{\mathrm{CA}}$ & $\begin{array}{l}53.3 \pm 2.7^{\circ \mathrm{CB}} \\
50.0 \pm 2.7^{\mathrm{C} C \mathrm{~B}} \\
54.2 \pm 1.7^{\mathrm{CB}}\end{array}$ \\
\hline $\begin{array}{l}\mathrm{FSH}+\mathrm{GH} / \mathrm{FSH}+\mathrm{GH}^{\S} \\
\mathrm{FSH}+\mathrm{GH} / \mathrm{FSH} \\
\mathrm{FSH}+\mathrm{GH} / \mathrm{GH}\end{array}$ & & $81.7 \pm 7.9^{-2 A}$ & $75.0 \pm 1.9^{-b A}$ & $\begin{array}{l}64.2 \pm 3.2^{\circ \mathrm{bB}} \\
63.3 \pm 2.7^{\circ \mathrm{bB}} \\
60.0 \pm 2.7^{\circ \mathrm{bB}}\end{array}$ \\
\hline
\end{tabular}

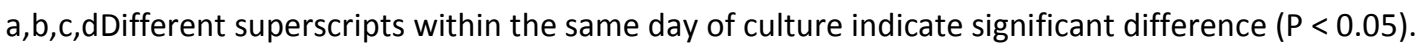

$A, B, C D i f f e r e n t$ superscripts within the same treatment indicate significant difference $(P<0.05)$.

$\S$ Groups initially cultured with the same substances (FSH or GH or FSH $+\mathrm{GH}$ ) have a common value on days 1 and 8.

* Differs significantly from the fresh control $(P<0.05)$.

\subsection{Activation of caprine primordial follicle after in vitro culture}

The percentage of activation of preantral follicles in the fresh control and after 1,8 or 16 days of in vitro culture is shown in Table 2. As early as day 1 of culture, when compared to 
the fresh control, a reduction $(P<0.05)$ in the percentage of primordial follicles concomitant with an increase $(P<0.05)$ of growing follicles was observed only in follicles cultured with FSH $+\mathrm{GH}$ in the first half of culture period $(\mathrm{FSH}+\mathrm{GH} / \mathrm{FSH}+\mathrm{GH}, \mathrm{FSH}+\mathrm{GH} / \mathrm{FSH}$ and $\mathrm{FSH}+\mathrm{GH} / \mathrm{GH})$. However, after 8 days of culture, an increase $(P<0.05)$ of growing follicles was observed in all treatments when compared to the fresh control. In addition, in all treatments, the percentage of growing follicles progressively increased $(P<0.05)$ throughout the culture period. Moreover, at day 16 of culture, the FSH/GH treatment showed the highest $(P<0.05)$ rate of growing follicles and produced more $(P<0.05)$ secondary follicles $(27 \%)$ when compared to all other treatments (range, 5-12\%).

Table 2

Percentages (mean $\pm S D$ ) of primordial and growing follicles in non-cultured tissues (fresh control) and in tissues cultured for 1,8 or 16 days in $\alpha-M E M+$ alone or $\alpha-M E M+$ containing GH and/or FSH.

\begin{tabular}{|c|c|c|c|c|c|c|c|c|}
\hline \multirow[t]{2}{*}{ Treatments } & \multicolumn{4}{|c|}{ Primordial follicles $(\%)$} & \multicolumn{4}{|c|}{ Growing follicles (\%) } \\
\hline & Day 0 & Day 1 & Day 8 & Day 16 & Day 0 & Day 1 & Day 8 & Day 16 \\
\hline Control & $94.5 \pm 2.1$ & - & - & - & $5.5 \pm 2.1$ & - & - & - \\
\hline$\alpha-\mathrm{MEM}^{+}$ & & $97.7 \pm 2.7^{\mathrm{aA}}$ & $78.7 \pm 6.1^{* a B}$ & $51.1 \pm 5.1^{\prime \prime a C}$ & & $2.4 \pm 2.7^{2 \mathrm{~A}}$ & $21.1 \pm 6.1^{-a B}$ & $49.0 \pm 5.1^{* a c}$ \\
\hline $\begin{array}{l}\mathrm{FSH}_{/} \mathrm{FSH}^{\S} \\
\mathrm{FSH} / \mathrm{GH} \\
\mathrm{FSH} / \mathrm{FSH}+\mathrm{GH}\end{array}$ & & $93.1 \pm 2.1^{\mathrm{AA}}$ & $44.9 \pm 1.1^{\mathrm{c} C \mathrm{~B}}$ & $\begin{array}{l}26.7 \pm 5.0^{\circ} \mathrm{cc} \\
14.0 \pm 1.9^{\circ} \mathrm{dc} \\
28.1 \pm 3.5^{\circ} \mathrm{cc}\end{array}$ & & $6.8 \pm 2.1^{2 A}$ & $55.1 \pm 1.1^{-\mathrm{cB}}$ & $\begin{array}{l}73.2 \pm 5.0^{\circ} \mathrm{cc} \\
84.9 \pm 1.9^{\circ} \mathrm{dc} \\
72.0 \pm 3.5^{\circ} \mathrm{cc}\end{array}$ \\
\hline $\begin{array}{l}\mathrm{GH} / \mathrm{GH}^{\S} \\
\mathrm{GH} / \mathrm{FSH} \\
\mathrm{GH} / \mathrm{FSH}+\mathrm{GH}\end{array}$ & & $93.9 \pm 2.6^{\mathrm{aA}}$ & $60.2 \pm 12.2^{-b B}$ & $\begin{array}{l}43.9 \pm 6.3^{-b c} \\
35.0 \pm 2.0^{-c} c \\
30.8 \pm 0.9^{-c c}\end{array}$ & & $6.1 \pm 2.6^{\mathrm{dA}}$ & $40.9 \pm 12.2^{\sim b B}$ & $\begin{array}{l}56.2 \pm 6.3^{-1} b c \\
65.0 \pm 2.0^{-1} \mathrm{cc} \\
69.2 \pm 0.9^{-\mathrm{cc}}\end{array}$ \\
\hline $\begin{array}{l}\mathrm{FSH}+\mathrm{GH} / \mathrm{FSH}+\mathrm{GH}^{\S} \\
\mathrm{FSH}+\mathrm{GH} / \mathrm{FSH} \\
\mathrm{FSH}+\mathrm{GH} / \mathrm{GH}\end{array}$ & & $88.6 \pm 2.7^{\prime \prime A A}$ & $47.7 \pm 3.2^{\circ \mathrm{bB}}$ & $\begin{array}{l}33.6 \pm 5.2^{\text {"cc }} \\
30.2 \pm 4.7^{-\mathrm{cc}} \\
27.6 \pm 6.6^{\prime c c}\end{array}$ & & $11.4 \pm 2.7^{\circ} \mathrm{bA}$ & $52.2 \pm 3.2^{-b B}$ & $\begin{array}{l}66.2 \pm 5.2^{*} \mathrm{cc} \\
69.7 \pm 4.7^{-\mathrm{cc}} \\
72.2 \pm 6.6^{* \mathrm{cc}}\end{array}$ \\
\hline
\end{tabular}

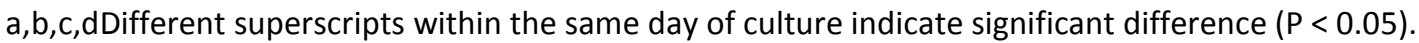
$A, B, C D i f f e r e n t$ superscripts within the same treatment indicate significant difference $(P<0.05)$. $\S$ Groups initially cultured with the same substances (FSH or GH or FSH $+\mathrm{GH}$ ) have a common value on days 1 and 8 .

* Differs significantly from the fresh control $(P<0.05)$.

\subsection{In vitro growth of caprine preantral follicles}

An increase in follicular diameter was observed in all treatments compared to the fresh control from day 1 of culture onwards $(P<0.05$; Table 3$)$. On day 1 of culture, the treatments with $\mathrm{FSH}+\mathrm{GH}$ had a larger $(\mathrm{P}<0.05)$ follicular diameter than those cultured with only $\alpha-$ $\mathrm{MEM}+$, but were similar to those cultured with FSH or GH. Furthermore, when the treatments were compared to each other on day 8, follicles cultured with FSH or FSH + GH in the first half of the culture had a larger $(P<0.05)$ follicular diameter than those initially cultured only with $\mathrm{GH}$ and MEM+ alone. After 16 days of culture, the FSH/GH treatment increased $(\mathrm{P}<0.05)$ follicular diameter when compared to the other treatments. From days 1 to 16 of culture, all treatments increased $(\mathrm{P}<0.05)$ follicular diameter, except FSH $+\mathrm{GH} / \mathrm{FSH}+\mathrm{GH}$ and FSH + 
GH/FSH ( $P>0.05$ ). Nevertheless, from day 8 to 16 of culture, only FSH/GH promoted an increase $(P<0.05)$ in follicular diameter.

Table 3

Follicle diameters (mean $\pm \mathrm{SD}$ ) in non-cultured tissues (fresh control) and in tissues cultured for 1,8 or 16 days in $\alpha-M E M+$ alone or $\alpha-M E M+$ containing GH and/or FSH.

\begin{tabular}{|c|c|c|c|c|}
\hline \multirow[t]{2}{*}{ Treatments } & \multicolumn{4}{|c|}{ Follicle diameter $(\mu \mathrm{m})$} \\
\hline & Day 0 & Day 1 & Day 8 & Day 16 \\
\hline Control & $34.2 \pm 3.6$ & & & \\
\hline$\alpha-\mathrm{MEM}^{+}$ & & $32.6 \pm 3.1^{\mathrm{bA}}$ & $34.0 \pm 3.1^{\circ \mathrm{CB}}$ & $34.8 \pm 1.8^{\swarrow \mathrm{dB}}$ \\
\hline $\begin{array}{l}\mathrm{FSH} / \mathrm{FSH}^{\frac{1}{3}} \\
\mathrm{FSH} / \mathrm{GH} \\
\mathrm{FSH} / \mathrm{FSH}+\mathrm{GH}\end{array}$ & & $36.4 \pm 2.9^{\circ} \mathrm{abA}$ & $40.2 \pm 3.0^{\circ \mathrm{aB}}$ & $\begin{array}{l}40.9 \pm 2.9^{\circ B} \mathrm{cB} \\
46.9 \pm 5.9^{\circ} \mathrm{C} \\
41.8 \pm 1.9^{\circ \mathrm{cB}}\end{array}$ \\
\hline $\begin{array}{l}\mathrm{GH} / \mathrm{GH}^{\S} \\
\mathrm{GH} / \mathrm{FSH} \\
\mathrm{GH} / \mathrm{FSH}+\mathrm{GH}\end{array}$ & & $37.8 \pm 3.4^{\prime \prime a A A}$ & $38.0 \pm 3.6^{\circ} \mathrm{bAB}$ & $\begin{array}{l}39.9 \pm 2.7^{\circ \mathrm{CB}} \\
41.0 \pm 1.0^{\mathrm{cB}} \\
40.6 \pm 1.9^{\mathrm{CB} B}\end{array}$ \\
\hline $\begin{array}{l}\mathrm{FSH}+\mathrm{GH} / \mathrm{FSH}+\mathrm{GH}^{\S} \\
\mathrm{FSH}+\mathrm{GH} / \mathrm{FSH} \\
\mathrm{FSH}+\mathrm{GH} / \mathrm{GH}\end{array}$ & & $38.6 \pm 1.8^{\circ \mathrm{a} A}$ & $39.9 \pm 2.5^{\circ} \mathrm{AB}$ & $\begin{array}{l}40.8 \pm 1.1^{\prime \mathrm{CAB}} \\
41.0 \pm 2.3^{\mathrm{CAB}} \\
43.2 \pm 2.8^{-\mathrm{bB}}\end{array}$ \\
\hline
\end{tabular}

$a, b, c, d N o$ common superscripts within the same day of culture indicate significant difference $(P<0.05)$. $A, B, C N o$ common superscripts within the same treatment indicate significant difference $(P<0.05)$. $\S$ Groups initially cultured with the same substances (FSH or GH or FSH $+\mathrm{GH}$ ) have a common value on days 1 and 8.

* Differs significantly from the fresh control $(P<0.05)$.

After day 1 of culture onwards there was an increase $(P<0.05)$ in oocyte diameter in all treatments compared to the fresh control ( Table 4). On day 8, there were no differences (P $>0.05$ ) in oocyte diameter among the treatments. However, after 16 days of culture, the FSH/GH treatment showed a higher $(\mathrm{P}<0.05)$ oocyte diameter, except when compared to $\mathrm{FSH} / \mathrm{FSH}$. With the progression of the culture period from 8 to 16 days, there was an increase $(\mathrm{P}<0.05)$ in oocyte diameter only in the culture performed with $\mathrm{FSH} / \mathrm{GH}$.

Table 4

Oocyte diameters (mean $\pm \mathrm{SD}$ ) in non-cultured tissues (fresh control) and in tissues cultured for 1,8 or 16 days in $\alpha-M E M+$ alone or $\alpha-M E M+$ containing $\mathrm{GH}$ and/or FSH.

\begin{tabular}{|c|c|c|c|c|}
\hline \multirow[t]{2}{*}{ Treatments } & \multicolumn{4}{|c|}{ Oocyte diameter $(\mu \mathrm{m})$} \\
\hline & Day 0 & Day 1 & Day 8 & Day 16 \\
\hline Control & $21.7 \pm 1.5$ & & & \\
\hline$\alpha-\mathrm{MEM}^{+}$ & & $22.7 \pm 1.8^{\prime \prime} \mathrm{BA}$ & $23.2 \pm 1.4^{2 \mathrm{AA}}$ & $23.4 \pm 1.5^{\mathrm{c} \mathrm{CA}}$ \\
\hline $\begin{array}{l}\mathrm{FSH} / \mathrm{FSH}^{\S} \\
\mathrm{FSH} / \mathrm{GH} \\
\mathrm{FSH} / \mathrm{FSH}+\mathrm{GH}\end{array}$ & & $22.8 \pm 1.1^{\mathrm{B}} \mathrm{bA}$ & $24.0 \pm 1.6^{-2 A B}$ & $\begin{array}{l}25.0 \pm 1.0^{-a b B} \\
26.6 \pm 3.0^{-a c} \\
23.4 \pm 2.4^{-c B}\end{array}$ \\
\hline $\begin{array}{l}\mathrm{GH} / \mathrm{GH}^{\S} \\
\mathrm{GH} / \mathrm{FSH} \\
\mathrm{GH} / \mathrm{FSH}+\mathrm{GH}\end{array}$ & & $23.2 \pm 1.1^{\text {"abA }}$ & $23.5 \pm 1.3^{2 \mathrm{~A}}$ & $\begin{array}{l}23.6 \pm 0.8^{*} \mathrm{CA} \\
23.8 \pm 1.0^{-\mathrm{CA}} \\
23.6 \pm 1.3^{\star \mathrm{CA}}\end{array}$ \\
\hline $\begin{array}{l}\mathrm{FSH}+\mathrm{GH} / \mathrm{FSH}+\mathrm{GH}^{\S} \\
\mathrm{FSH}+\mathrm{GH} / \mathrm{FSH} \\
\mathrm{FSH}+\mathrm{GH} / \mathrm{GH}\end{array}$ & & $23.7 \pm 0.8^{\prime \prime A A}$ & $23.7 \pm 1.2^{-2 A}$ & $\begin{array}{l}23.7 \pm 0.9^{-\mathrm{CA}} \\
23.8 \pm 1.3^{-\mathrm{CA}} \\
24.3 \pm 2.5^{\circ \mathrm{bA}}\end{array}$ \\
\hline
\end{tabular}

$a, b, c$ No common superscripts within the same day of culture indicate significant difference $(P<0.05)$. $A, B, C N o$ common superscripts within the same treatment indicate significant difference $(P<0.05)$. $\S$ Groups initially cultured with the same substances (FSH or GH or FSH $+\mathrm{GH}$ ) have a common value on days 1 and 8.

* Differs significantly from the fresh control $(P<0.05)$. 


\subsection{Ultrastructural features of caprine preantral follicles}

For a better evaluation of follicular integrity, ultrastructural analysis of preantral follicles was performed in fresh control samples, cultured control samples (16 days in $\alpha$ $\mathrm{MEM}+$ ), as well as in samples cultured with FSH for 8 days and FSH/GH for 16 days These last two treatments were selected for generating the best overall results in the parameters evaluated by histological analysis.

Ultrastructural features of follicles evaluated in the fresh control, treatments containing FSH alone (day 8) and FSH/GH treatment (day 16) were normal and showed preserved oocytes with intact plasma and nuclear membranes, and large oocyte nuclei (Fig. $3 \mathrm{~A}, \mathrm{~B}$, and $\mathrm{C}$, respectively). A slight increase in cytoplasmic vacuolization was observed from days 0 to 16 of culture. However, the organelles were uniformly distributed in the ooplasm, especially the mitochondria and endoplasmic reticulum. Ultrastructurally, granulosa cells were normal and well organized around the oocytes, showing large nuclei with irregular shapes and a high proportion of nuclei-to-cytoplasm area. Nevertheless, follicles cultured in $\alpha-M E M+$ for 16 days (cultured control) showed signs of degeneration, such as high levels of cytoplasmic vacuolization, low-densities of organelles and loss of cytoplasm as atresia progressed (Fig. 3D).
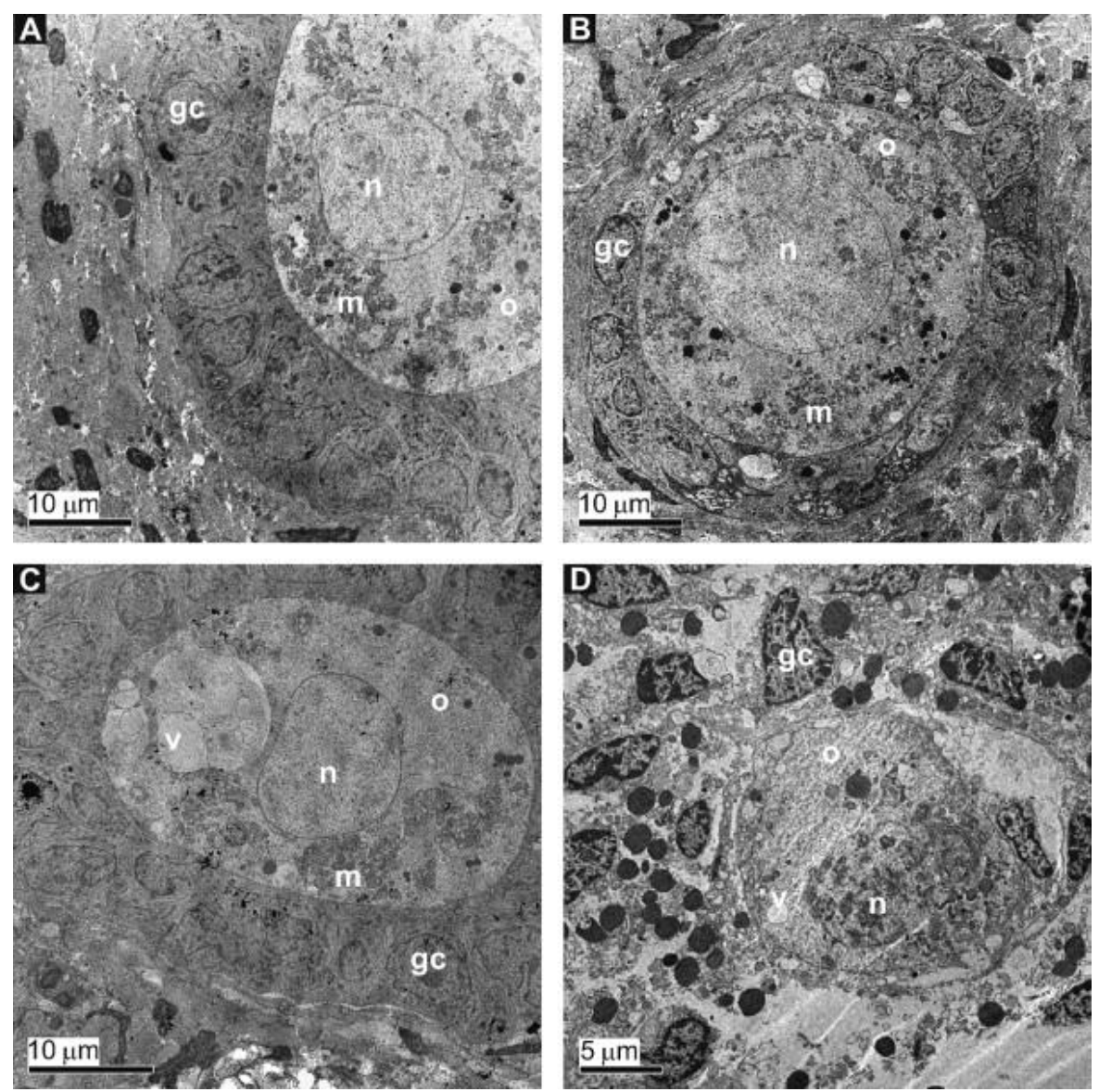
Fig. 3. Electron micrographs of follicles before and after 8 or 16 days of culture. (A) Normal preantral follicle from noncultured ovarian tissue (fresh control). (B) Normal preantral follicle after 8 days of in vitro culture in the FSH treatment. (C) Normal preantral follicle after 16 days of in vitro culture in the FSH/GH treatment. (D) Degenerated follicle after in vitro culture in $\alpha-\mathrm{MEM}+$ alone for 16 days. $\mathrm{o}=$ oocyte; $\mathrm{n}$ = oocyte nucleus; $\mathrm{m}$ = mitochondria; $\mathrm{v}$ = vacuole; gc = granulosa cell.

\subsection{Assessment of preantral follicle viability}

For the viability analysis, 90 caprine preantral follicles were analyzed by fluorescence microscopy before (fresh control) and after 16 days of culture in $\alpha-M E M+$ alone (cultured control; Fig. 4B) and in the FSH/GH treatment (Fig. 4A). A follicle after culture in FSH/GH labeled with calcein-AM (green fluorescence), and a follicle marked with ethidium homodimer1 (red fluorescence) after culture in $\alpha-M E M+$ alone are shown (Fig. 4C and D, respectively). Based on quantitative analysis, follicles cultured in $\mathrm{FSH} / \mathrm{GH}$ had the highest $(\mathrm{P}<0.05)$ follicular viability $(70 \%)$ among treated groups, however the viability was lower $(P<0.05)$ when compared to the fresh control (93\%). Furthermore, follicles cultured in the absence of FSH and GH $(\alpha-M E M+$ alone) showed a reduced $(P<0.05)$ viability $(20 \%)$ compared to the fresh control and $\mathrm{FSH} / \mathrm{GH}$.
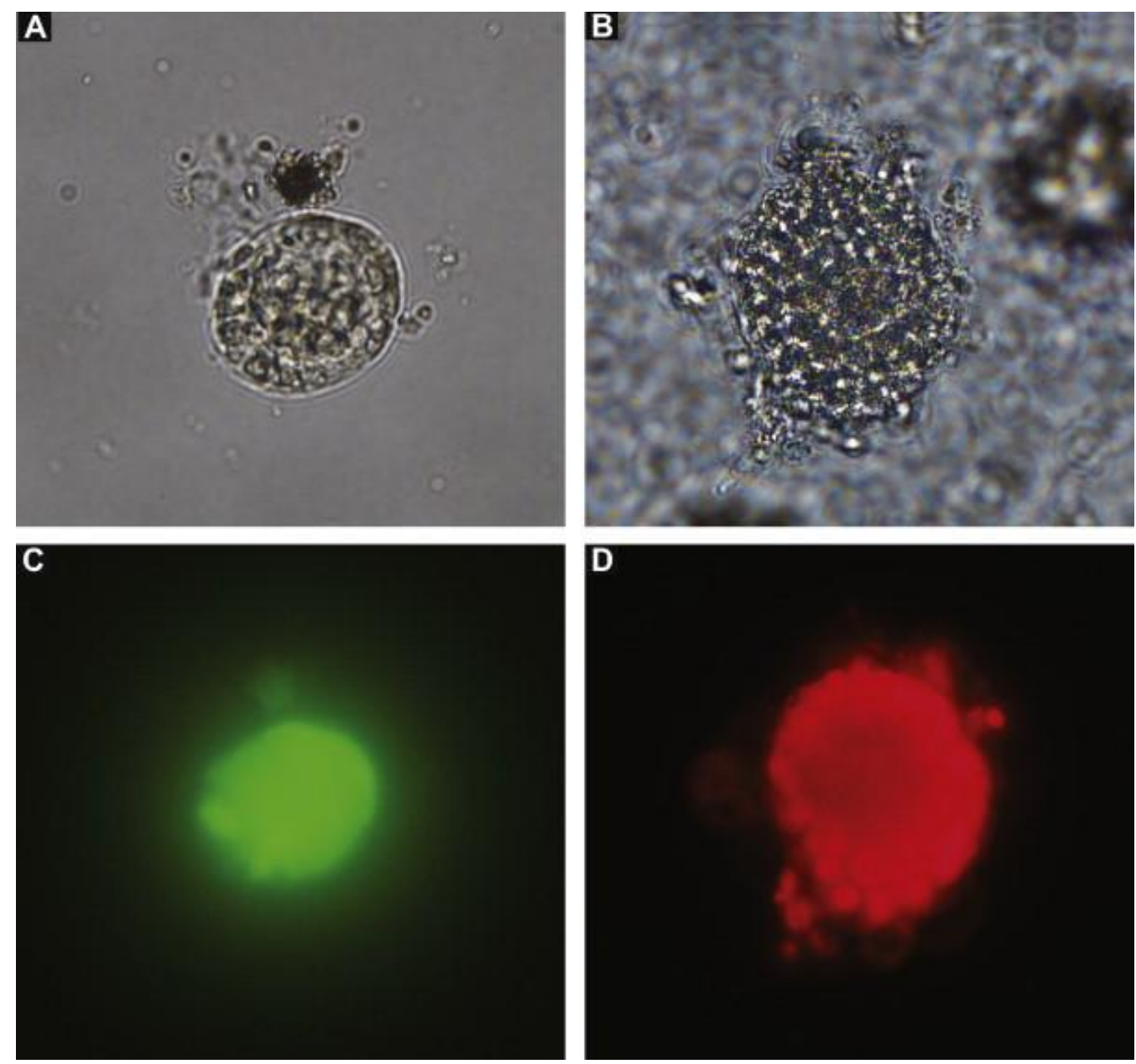
Fig. 4. Isolated (A) normal preantral follicle cultured in the FSH/GH treatment and (B) degenerated follicle cultured in $\alpha-M E M+$ alone for 16 days. The viability assessment of follicles (A) and (B) by fluorescent probes shows (C) viable follicle stained with calcein-AM (green fluorescence) and (D) nonviable follicle labeled with ethidium homodimer-1 (red fluorescence). (For interpretation of the references to color in this figure legend, the reader is referred to the web version of the article.)

\section{Discussion}

The present study demonstrated the importance of a sequential medium on early in vitro folliculogenesis in goats. Herein we showed, for the first time, the positive effects of a sequential medium containing FSH followed by GH on the survival, activation and growth of caprine preantral follicles during long-term in vitro culture. A recent study on ovine cortical tissue demonstrated that growth factors added sequentially on different days of culture is crucial for a successful in vitro culture system ( Peng et al., 2010).

In this study, after 1 day of culture, the treatments with FSH alone or FSH with GH showed higher percentages of follicular survival than other treatments. Additionally, only the treatments with FSH alone were similar to the fresh control. Moreover, the highest percentage of normal follicles after 16 days was found in the treatment with FSH in the first half of culture and $\mathrm{GH}$ in the second half of the culture (FSH/GH). This treatment was the only one that maintained follicular survival from days 8 to 16 of culture. This result was confirmed by fluorescence analysis which showed that follicles cultured in FSH/GH had the highest follicular viability among treated groups. In general, the percentage of follicular survival (histological analysis) was higher than the percentage of viability (fluorescence analysis). This finding was expected once that the fluorescence analysis is more accurate and allows the detection of functional aspects of the cell, such as esterase activity. It has been shown that FSH maintains the survival of caprine preantral follicles (Saha et al., 2000, Matos et al., 2007 and Magalhães et al., 2009). Indeed, this hormone has an inhibitory effect on apoptosis in preantral follicles cultured in vitro in several species (mouse: Baker and Spears, 1997; human: Wright et al., 1999; pig: Mao et al., 2002). In mice, the omission of FSH from the culture medium resulted in follicular cell death and a reduction in granulosa cell vitality ( Cortvrindt et al., 1997). Although FSH receptors do not seem to be expressed in granulosa cells of primordial follicles, this hormone may act indirectly through paracrine factors secreted by larger follicles or stroma cells. FSH promotes proliferation of granulosa cells by paracrine factors, such as insulin-like growth factor 1 (IGF-1) and activin A ( Van den Hurk and Zhao, 2005). The positive effect of FSH in the first half of in vitro culture when compared with the other treatments might be related to the fact that FSH can regulate the expression of several genes, such as KL, GDF-9 and BMP- 
15 in ovarian follicles ( Joyce et al., 1999 and Thomas et al., 2005), which have been involved in activation of primordial follicles (Van den Hurk and Zhao, 2005).

With respect to $\mathrm{GH}$, this hormone was able to maintain follicular survival in the second half of the culture. The results of a study performed by Hull and Harvey (2001) suggest that GH stimulates growth and prevents atresia in small follicles. In vitro studies have shown that GH has a direct inhibitory effect on apoptosis in early bovine (Sirotkin and Makarevich, 1999) and rat ( Eisenhauer et al., 1995 and Chun and Hsueh, 1998) follicles. The mechanism by which GH regulates survival in ovarian follicles is not exactly known yet. It is quite possible that GH may act through direct stimulation of other regulatory factors, such as insulin and IGF-I, which can play an important role in follicular survival.

In our study, after 8 days of culture, the treatments initially cultured with FSH showed the highest follicular activation when compared to $\alpha-M E M+$ alone and the other treatments. Recent studies demonstrated that FSH improved the activation of caprine preantral follicles after 7 days of culture (Matos et al., 2007 and Magalhães et al., 2009). Oktay et al. (1997) reported that the expression of FSH receptors developed progressively during the transition from primordial to primary and secondary follicles in human ovaries. The presence of FSH receptors in granulosa cells of preantral follicles suggests that FSH can promote early follicular development and growth.

Furthermore, after 16 days of culture, the treatment that received GH from day 8 to day $16(\mathrm{FSH} / \mathrm{GH})$ promoted the highest rate of follicular activation and the highest percentage of secondary follicles. The local action of GH may have been through an autocrine or paracrine mechanism, although the systemic actions (i.e., endocrine mechanism) of GH have been more reported. The GH receptor and its mRNA have been located in the ovaries of various species: rat ( Ranke et al., 1976 and Carlsson et al., 1993); human ( Sharara and Nieman, 1994); sheep ( Eckery et al., 1997); and cow ( Kölle et al., 1998 and Izadyar et al., 1999). Using recombinant human GH, Liu et al. (1998) demonstrated that earlier phases of follicular development in mice are controlled by $\mathrm{GH}$, which stimulates secondary follicle formation in vitro. Furthermore, Kobayashi et al. (2000) showed a stimulatory effect of GH on the proliferation of granulosa cells in murine preantral follicles. The rate of follicular activation in control medium ( $\alpha-M E M+$ alone) found in this study was lower than previous studies from the same research group. This fact can be explained once in the current experiment the intermediate follicles (one layer of flattened and cuboidal granulosa cells) were included in the primordial follicle category.

Our results on follicle morphology, based on classical histology, were confirmed by fluorescence and ultrastructural analyses. These methodologies are considered to be important tools for detecting damage to cellular membranes and organelles, respectively. 
Transmission electron microscopy was used as a qualitative and supplementary technique to evaluate follicular integrity after in vitro culture ( Lucci et al., 2001). In the present study, preantral follicles from the fresh control and those cultured in FSH for 8 days and FSH/GH for 16 days showed intact oocytes and granulosa cells, which displayed a preserved ultrastructure, with intact mitochondria and endoplasmic reticula, as well as the basement, plasma and nuclear membranes.

In conclusion, the present study provides the first evidence of a positive effect of a sequential medium supplemented with FSH and GH on early in vitro folliculogenesis in goats. The treatment with FSH followed by GH maintained follicular survival and ultrastructural integrity and promoted the activation of primordial follicles and subsequent progression to secondary follicles. This finding shall be very useful in the future to simulate the in vivo ovarian environment, optimizing culture systems to allow complete follicular development in vitro.

\section{Acknowledgments}

This research was supported by grants from the National Council for Scientific and Technological Development (CNPq, Brazil, grant number 554812/2006-1 - RENORBIO; Pronex) and Brazilian Innovation Agency (FINEP). Deborah de Melo Magalhães Padilha is the recipient of a grant from CNPq (Brazil). The authors thank Nanocore for donating recombinant FSH and Keith T. Haag for assistance in manuscript preparation.

\section{References}

Arunakumari, G., Shanmugasundaram, N., Rao, V.H., 2010. Development of morulae from the oocytes of cultured sheep preantral follicles. Theriogenology 74, 884-894. Baker, S.J., Spears, N., 1997. Follicle stimulating hormone inhibits apoptosis in pre- and early- antral murine follicles in vitro. J. Reprod. Fertil. 40, 19-21.

Carlsson, B., Bergh, C., Bentham, J., Olsson, J.H., Norman, M.R., Billig, H., Roos, P., Hillensjo, T., 1992. Expression of functional growth hormone receptors in human granulosa cells. Hum. Reprod. 7, 1205-1209.

Carlsson, B., Nilsson, A., Isaksson, O.G.P., Billig, H., 1993. Growth hormonereceptor messenger RNA in the rat ovary-regulation and localization. Mol. Cell. Endocrinol. 95, 59-66.

Celestino, J.J.H., Bruno, J.B., Lima-Verde, I.B., Matos, M.H., Saraiva, M.V., Chaves, R.N., Martins, F.S., Almeida, A.P., Cunha, R.M., Lima, L.F., Name, K.P., Campello, C.C., Silva, J.R., Báo, S.N., Figueiredo, J.R., 2010. Steady state level of kit ligand mRNA in goat ovaries and the role of kit ligand in preantral follicle survival and growth in vitro. Mol. Reprod. Dev. 77, 231-240. 
Chaves, R.N., Martins, F.S., Saraiva, M.V., Celestino, J.J., Lopes, C.A., Correia, J.C., Verde, I.B., Matos, M.H., Báo, S.N., Name, K.P., Campello, C.C., Silva, J.R.V., Figueiredo, J.R., 2008. Chilling ovarian fragments during transportation improves viability and growth of goat preantral follicles cultured in vitro. Reprod. Fertil. Dev. 20, 640-647.

Chun, S.Y., Hsueh, A.J., 1998. Paracrine mechanisms of ovarian follicle apoptosis. J. Reprod. Immunol. 39, 63-75. Cortvrindt, R., Smitz, J., Van Steirteghem, A.C., 1997. Assessment of the need for follicle stimulating hormone in early preantral mouse follicle culture in vitro. Hum. Reprod. 12, 759-768.

Daniel, S.A.J., Armstrong, D.T., Gorelangton, R.E., 1989. Growth and development of rat oocytes in vitro. Gam. Res. 24, 109-121.

Eckery, D.C., Moeller, C.L., Nett, T.M., Sawyer, H.R., 1997. Localization and quantification of binding sites for follicle-stimulating hormone, luteinizing hormone, growth hormone, and insulin-like growth factor I in sheep ovarian follicles. Biol. Reprod. 57, 507-513.

Eisenhauer, K.M., Chun, S.Y., Billig, H., Hsueh, A.J., 1995. Growth hormone suppression of apoptosis in preovulatory rat follicles and partial neutralization by insulin-like growth factor binding protein. Biol. Reprod. 53, 13-20.

Gougeon, A., 1996. Regulation of ovarian follicular development in primates: facts and hypotheses. Endocr. Rev. 17, 121-154.

Gupta, P.S.P., Ramesh, H.S., Manjunatha, B.M., Nandi, S., Ravindra, J.P., 2008. Production of buffalo embryos using oocytes from in vitro grown preantral follicles. Zygote 16, 57-63.

Hull, K.L., Harvey, S., 2001. Growth hormone: roles in female reproduction. J. Endocr. 168, 123. Hulshof, C.J., Figueiredo, J.R., Beckers, J.F., Bevers, M.M., Van Den Hurk, R., 1994. Isolation and characterization of preantral follicles from foetal bovine ovaries. Vet. Q. 16, 78-80.

Izadyar, F., Zhao, J., van Tol, H.T.A., Colenbrander, B., Bevers, M.M., 1999. Messenger RNA expression and protein localization of growth hormone in bovine ovarian tissue and in cumulus oocyte complexes (COCs) during in vitro maturation. Mol. Reprod. Dev. 53, 398-407.

Joyce, I.M., Pendola, F.L., Wigglesworth, K., Eppig, J.J., 1999. Oocyte regulation of Kit ligand expression in mouse ovarian follicles. Dev. Biol. 214, 342-353.

Kobayashi, J., Mizunuma, H., Kikuchi, N., Liu, X., Andoh, K., Abe, Y., Yokota, H., Yamada, K., Ibuki, Y., Hagiwara, H., 2000. Morphological assessment of the effect of growth hormone on preantral follicles from 11-day-old mice in an in vitro culture system. Biochem. Biophys. Res. Commun. 268, 36-41.

Kölle, S., Sinowatz, F., Boie, G., Lincoln, D., 1998. Developmental changes in the expression of the growth hormone receptor messenger ribonucleic acid and protein in the bovine ovary. Biol. Reprod. 58, 836-842. 
Liu, X., Andoh, K., Yokota, H., Kobayashi, J., Abe, Y., Yamada, K., Mizunuma, H., Hibuki, Y., 1998. Effects of growth hormone, activin, and follistatin on the development of preantral follicle from immature female mice. Endocrinology 139, 2342-2347.

Lucci, C.M., Amorim, C.A., Báo, S.N., 1999. Effect of the interval of serial sections of ovarian in the tissue chopper on the number of isolated caprine preantral follicles. Anim. Reprod. Sci. 56, 39-49.

Lucci, C.M., Silva, R.V., Carvalho, C.A., Figueiredo, J.R., Báo, S.N., 2001. Light microscopical and ultrastrutural characterization of goat preantral follicles. Small Rumin. Res. 41, 61-69

Magalhães, D.M., Araújo, V.R., Lima-Verde, I.B., Matos, M.H.T., Silva, R.C., Lucci, C.M., Báo, S.N., Campelo, C.C., Figueiredo, J.R., 2009. Different follicle-stimulating hormone (FSH) sources influence caprine preantral follicle viability and development in vitro. Braz. J. Vet. Res. Anim. Sci. $46,378-386$.

Magalhães, D.M., Duarte, A.B.G., Araújo, V.R., Brito, I.R., Soares, T.G., Lima, I.M., Lopes, C.A., Campello, C.C., Rodrigues, A.P., Figueiredo, J.R., 2011. In vitro production of a caprine embryo from a preantral follicle cultured in media supplemented with growth hormone. Theriogenology 75, 182-188.

Mao, J., Wu, G., Smith, M.F., 2002. Effects of culture medium, serum type, and various concentrations of follicle stimulating hormone on porcine preantral follicular development and antrum formation in vitro. Biol. Reprod. 67, 1197-1203.

Martins, F.S., Celestino, J.J.H., Saraiva, M.V.A., Matos, M.H.T., Bruno, J.B., Rocha-Junior, C.M., Lima-Verde, I.B., Lucci, C.M., Báo, S.N., Figueiredo, J.R., 2008. Growth and differentiation factor-9 stimulates activation of goat primordial follicles in vitro and their progression to secondary follicles. Reprod. Fertil. Dev. 20, 916-924.

Matos, M.H.T., Lima-Verde, I.B., Luque, M.C.A., Maia Jr., J.E., Silva, J.R., Celestino, J.J., Martins, F.S., Báo, S.N., Lucci, C.M., Figueiredo, J.R., 2007. Essential role of follicle stimulating hormone in the maintenance of caprine preantral follicle viability in vitro. Zygote 15, 173-182.

O’Brien, M.J., Pendola, J.K., Eppig, J.J., 2003. A revised protocol for in vitro development of mouse oocyte from primordial follicles dramatically improves their development competence. Biol. Reprod. 68, 1682-1686.

Oktay, K., Briggs, D., Gosden, R.G., 1997. Ontogeny of follicle-stimulating hormone receptor gene expression in isolated human ovarian follicles. J. Clin. Endocrinol. Metab. 82, 3748-3751.

Peng, X., Yang, M., Wang, L., Tong, C., Guo, Z., 2010. In vitro culture of sheep lamb ovarian cortical tissue in a sequential culture medium. J. Assist. Reprod. Genet. 27, 247-257.

Ranke, M.B., Stanley, C.A., Rodbard, D., Baker, L., Bongiovanni, A., Parks, J.S., 1976. Sex differences in binding of human growth hormone to isolated rat hepatocytes. Proc. Natl. Acad. Sci. U.S.A. $73,847-851$. 
Saha, S., Shimizu, M., Geshi, M., Izaike, Y., 2000. In vitro culture of bovine preantral follicles. Anim. Reprod. Sci. 63, 27-39.

Sharara, F.I., Nieman, L.K., 1994. Identification and cellular localization of growth hormone receptor gene expression in the human ovary. J. Clin. Endocrinol. Metab. 79, 670-672.

Sirotkin, A.V., Makarevich, A.V., 1999. GH regulates secretory activity and apoptosis in cultured bovine granulosa cells through the activation of the cAMP/protein kinase a system. J.

Endocrinol. 163, 317-327.

Skinner, M.K., 2005. Regulation of primordial follicle assembly and development. Hum.

Reprod. 11, 461-471.

Thomas, F.H., Ethier, J.F., Shimasaki, S., Vanderhyden, B.C., 2005. Folliclestimulating hormone regulates oocyte growth by modulation of expression of oocyte and granulosa cell factors.

Endocrinology 146, 941-949.

Van den Hurk, R., Zhao, J., 2005. Formation of mammalian oocytes and their growth, differentiation and maturation within ovarian follicles. Theriogenology 63, 1717-1751.

Wang, X., Catt, S., Pangestu, M., Temple-Smith, P., 2011. Successful in vitro culture of preantral follicles derived from vitrified murine ovarian tissue: oocyte maturation, fertilization, and live births. Reproduction 141, 183-191.

Wright, C.S., Hovatta, O., Margara, R., Trew, G., Winston, R.M.L., Franks, S., Hardy, K., 1999. Effects of follicle-stimulating hormone and serum substitution on the in vitro growth of human ovarian follicles. Hum. Reprod. 14, 1555-1562.

Wu, J., Carrel, D.T., Wilcox, A.L., 2001. Development of in vitro-matured oocytes from porcine preantral follicles following intracytoplasmic sperm injection. Biol. Reprod. 65, 1579-1585. 